\title{
ArcheoSciences
}

Revue d'archéométrie

33 (suppl.) | 2009

Mémoire du sol, espace des hommes

\section{Geophysical surveying in Egypt: periodic report for 2007-2008}

\section{Tomasz Herbich}

\section{Q OpenEdition \\ 1 Journals}

\section{Electronic version}

URL: https://journals.openedition.org/archeosciences/1316

DOI: 10.4000/archeosciences.1316

ISBN: 978-2-7535-1599-4

ISSN: 2104-3728

Publisher

Presses universitaires de Rennes

\section{Printed version}

Date of publication: 30 October 2009

Number of pages: $73-76$

ISBN: 978-2-7535-0943-6

ISSN: $1960-1360$

\section{Electronic reference}

Tomasz Herbich, "Geophysical surveying in Egypt: periodic report for 2007-2008", ArcheoSciences

[Online], 33 (suppl.) | 2009, Online since 30 October 2011, connection on 01 February 2022. URL:

http://journals.openedition.org/archeosciences/1316; DOI: https://doi.org/10.4000/archeosciences. 1316 


\title{
Geophysical surveying in Egypt: periodic report for 2007-2008
}

\author{
Tomasz Herbich *
}

key words: Magnetic method, Resistivity method, Vertical electrical soundings method, Egypt, Archaeological verification.

Recent research in Egypt has demonstrated pointedly the magnetic method's uses both in the early recognition of a site prior to full-scale excavations and in data collection for better planning of ongoing explorations. The electrical resistivity method has seen much broader use than before. The present article is concerned with the author's work in 2007 and 2008, reports on earlier results having been presented at conferences in Vienna (Herbich ,2001), Kraków (Herbich, 2003), Rome (Herbich, 2005) and Nitra (Herbich, 2007).

Projects at Nabta Playa, Abydos, Tell el-Dab'a, Gurob, Tell el-Borg, Tell el-Balamun, Tell el-Herr, Pelusium, Ayn Birbiyeh and Bawit were continued. New projects included investigations at Nag el-Qarmila, El-Amra, Tell er-Retaba, North Saqqara, Tell el-Hebua, Tell el-Abiad, Deir el-Banat.

Two methods were in use: magnetic and electrical resistivity. Geoscan Research FM 256 gradiometers were used for the magnetic mapping, always in parallel mode, 8 sampling points per sq $\mathrm{m}$. Electrical resistivity was measured with RM15 ${ }^{1}$, and the Polish-made resistivity meter ADA-05 (by Elmes).

Nabta Playa (Western Desert, Prehistoric Combined Expedition). Continued electrical resistivity survey (Schlumberger array, $\mathrm{AB}=6 \mathrm{~m}$ ) recording monadrocks under concentrations of Neolithic megaliths. Two concentrations of megaliths were investigated.
Nag el-Qarmila (Wadi Kubbaniya, Upper Egypt, British Musem/Yale University). Magnetic survey; recording settlement remains of the Predynastic period.

El-Amra (Upper Egypt, University of Pennsylvania/Yale University/Institute of Fine Arts project). Magnetic survey in the area of a Predynastic cemetery north of a section explored in the early 20th century (Fig. 1). Excavations confirmed the mapping results which had suggested a village in this area: two sets of features corresponded to two settlement areas containing remains of mud-brick walls and mud plaster floors, surrounded by exterior walls of mud and cobbles. Artifact assemblages appear consistent with Predynastic/Nagada II-III culture. Should the site chronology and character be verified in further excavations, the discovery would count among the most important in view of a general dearth of settlement data from this period from Upper Egypt.

Northern Cemetery in Abydos (Upper Egypt, University of Pennsylvania/Yale University/Institute of Fine Arts project). Magnetic surveying led to a relocation of cemetery D (Old Kingdom mud brick mastabas) excavated by Thomas E. Peet in the early 20th century.

Tell el-Retaba (Western Delta, Polish Centre of Mediterranean Archaeology and Slovak Academy of

\footnotetext{
* Institute of Archaeology and Ethnology, Polish Academy of Sciences Al. Solidarnosci 105, 00-140 Warsaw, Poland. (tomasz.herbich@gmail.com) (herbich@iaepan.edu.pl)

1. One of gradiometers and RM15 were provided by the Programma de Estudios de Egiptolgía (Consejo Nacional de Investigationes Cientifícas y Técnicas, Buenos Aires) on the grounds of a co-operation agreement with the Polish Centre of Mediterranean Archaeology of the University of Warsaw.
} 


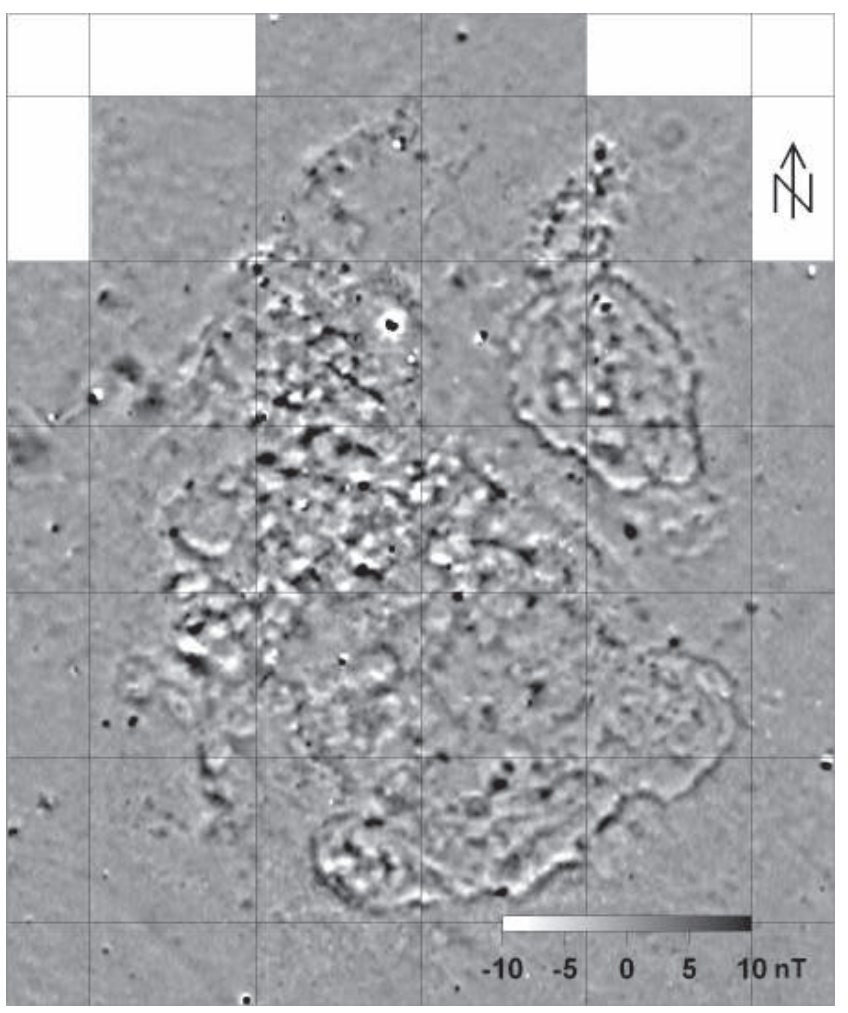

Figure 1: El-Amra, Magnetic map of the Predynastic settlement. Geoscan Research FM256. Sampling grid 0.25 by $0.5 \mathrm{~m}$. Grid lines every $20 \mathrm{~m}$.

Sciences). The objective being a plan of this Middle Kingdom - Late Period site explored by W. M. Flinders Petrie, a magnetic survey was conducted mapping architectural remains inside the walls and determining precisely the course of the defences surrounding the settlement. Since a Slovak team had completed a electromagnetic survey earlier in 2007 , it was subsequently possible to compare the efficiency of the two geophysical methods on a site with mud brick architecture in sandy terrain.

Tell el-Dab'a (Western Delta, Austrian Archaeological Institute in Cairo, magnetic prospection jointly with $\mathrm{Ch}$. Schweitzer). Surveying methodology was developed and tested, starting with preliminary site recognition (recording settlement areas, tracing the ancient bed of the Nile and extent of floodplains) by the caesium magnetometer Scintrex SM-4/4G system, followed by more detailed studies with fluxgate FM256 gradiometers of areas with recognized architectural remains. Since 1999 the survey has covered an area of 130 ha, including the towns of the Middle Kingdom, Hyksos domination and New Kingdom periods. A project to trace the ancient Nile river bed by vertical electrical soundings has been implemented jointly with the Institute of Archaeology and Ethnology, Polish Academy of Sciences, since 2008.

Gurob (Fayum, Liverpool University). Magnetic survey registered the remains of industrial activity in areas neighboring with the town from the New Kingdom.

Saqqara North (Waseda University). The magnetic mapping objective was to check for structures to the south of the New Kingdom complex excavated by the expedition. None were recorded.

Tell el-Hebua (North Sinai, Supreme Council of Antiquities of Egypt). The magnetic survey inside a New Kingdom fortress led to the discovery of an unknown temple (of the New Kingdom period) as well as remains of Roman-age architecture.

Tell el-Borg (North Sinai, Trinity University). Magnetic prospection revealed the presence of a hitherto unknown fort presumably of New Kingdom date.

Tell el-Abiad (North Sinai, Sorbonne University). Magnetic surveying provided a plan of a small fort, which was dated to the Nineteenth Dynasty following some archaeological excavations (Fig. 2).

Tell el-Herr (North Sinai, Sorbonne University). The objective of a test magnetic survey ( $0.5 \mathrm{ha})$ was to record architectural remains south of the Late Period fortress.

Pelusium (Northern Sinai, Polish Centre of Mediterranean Archaeology, University of Warsaw). Continued prospection of area between the northern edge of the town and the Roman theatre, east of the Byzantine fort. The extent of an urban district including public structures among typically private residential architecture of Late Antique date was determined. Counted among the public structures is

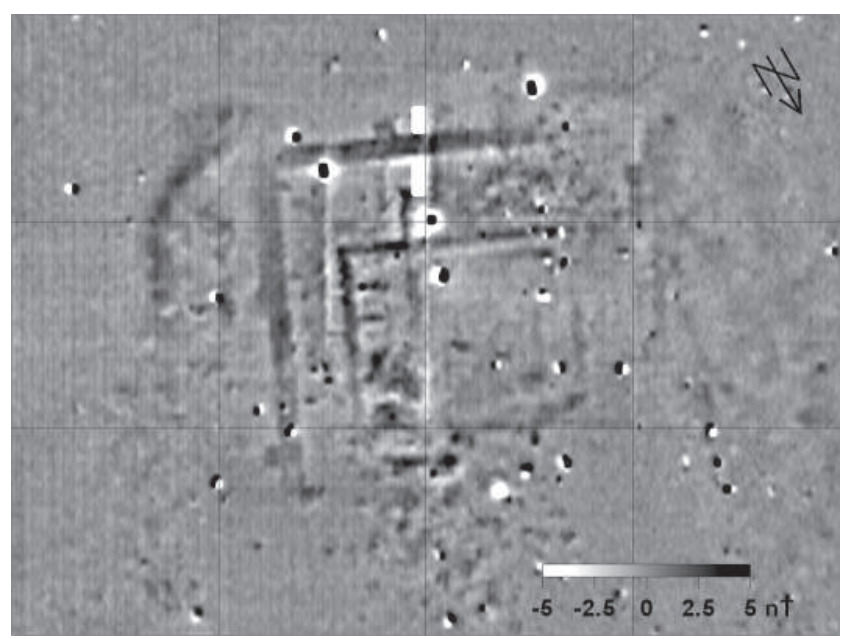

Figure 2: Tell el-Abiad, Magnetic map of the New Kingdom fort. Geoscan Research FM256. Sampling grid 0.25 by $0.5 \mathrm{~m}$. Grid lines every $20 \mathrm{~m}$. 
a huge round building with a diameter of $35 \mathrm{~m}$. Moreover a street grid was mapped. Electrical resistivity prospection (twin probe array, $\mathrm{AM}=0.5 \mathrm{~m}$ ) provided a detailed plan of a number of structures (Fig. 3).

Deir el-Banat (Fayum Oasis, Russian Institute of Egyptology in Cairo). A test of the magnetic method on this site (1 ha) checked for the method's efficiency in surveying a heavily looted Ptolemaic-Roman cemetery. Some remains of tomb architecture were found, but the piles of red-bricks coming from looted tombs limit the method's usefulness.

Ayn Birbiyeh (Dakhleh Oasis, Dakhleh Oasis Project). Resistivity survey (twin probe, $A M=1 \mathrm{~m}$ ) registerered walls surrounding Roman temple built of local sandstone.

Bawit (Middle Egypt, Louvre Museum). Completed magnetic prospection of the site covering a total of 40 ha, began in 2004. Magnetic mapping analysis helped to pinpoint exact locations of almost all of the features in the northern part of the site excavated by a French expedition digging in the early 20th century. It also helped to understand the planning of church complexes in the town center (mistakenly recorded by the early excavators). The magnetic results provided grounds for drawing a plan of the ancient settlement including the street grid, Coptic monastic complexes and areas of industrial activity.

The work carried out at Tell el-Balamun has been reported in another paper in this volume.
Figure 3: Pelusium. Magnetic map of the Late Antiquity urban district (Geoscan Research FM256; sampling grid 0.25 by $0.5 \mathrm{~m}$ ) and fragment of resistivity map superimposed (RM15, twin-probe $A M=0.5 \mathrm{~m}$, sampling grid 0.5 by 1 $\mathrm{m}$, interpolated to $0.5 \mathrm{~m}$; low pass filter). Grid lines every $20 \mathrm{~m}$.

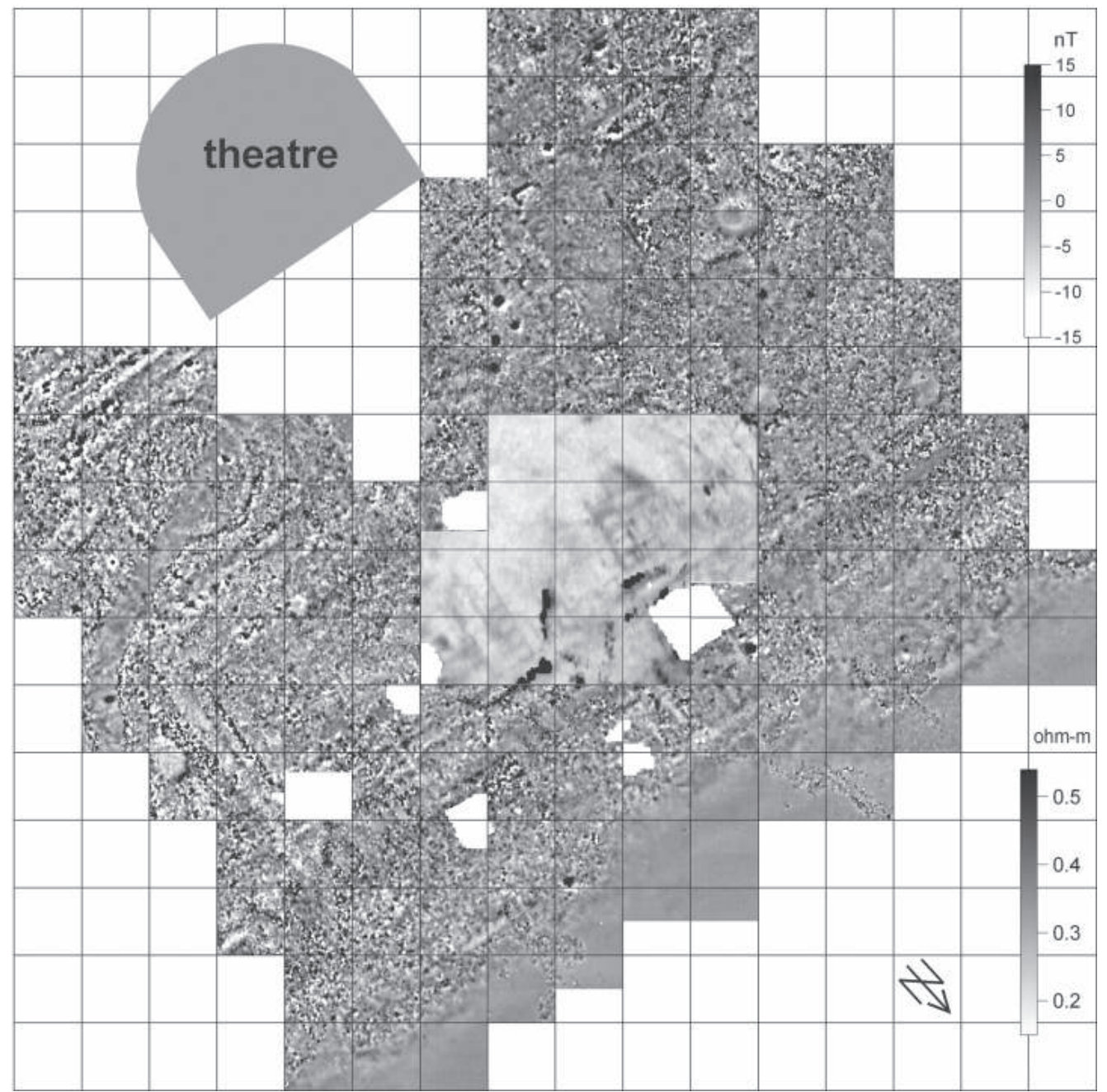




\section{References}

Herbich, T., 2001. Archaeological geophysics in Egypt: recent results. In Doneus, M., Eder-Hinterleitner, A., Neuebauer, W. (dir.) Archaeological Prospection, $4^{\text {th }}$ International conference on archaeological prospection, 112-114.

Herbich, T., 2003. Archaeological geophysics in Egypt: the Polish contribution, Archaeologia Polona, 41: 13-55.
Herbich, T., 2005. Geophysical surveying in Egypt: recent results, in Piro, S., (dir.). VI conference on Archaeological Prospection, 1-5.

Herbich, T., 2007. Geophysical surveying in Egypt: periodic report for 2005-2006, in Kuzma, I., Tirpak, J., (dir.). VII conference on Archaeological Prospection, Studijne zvesti Archeologickeho ustavu, SAV 41: 188-191. 